\title{
ALGORITHM FOR PRODUCTS FINAL CONSUMPTION STRUCTURE ANALYSIS IN DEGENERATE DYNAMIC INPUT-OUTPUT MODEL
}

T. A. Vinogradova, South Ural State University, Chelyabinsk, Russian Federation, shishkinata@susu.ru

The article presents an algorithm for products final consumption structure analysis. Such an algorithm for the base year allows to correctly determine the column-vector of final consumption of products in Degenerate Dynamic Input-Output Model of enterprise. The main idea of the algorithm is to include in the structure of the column-vector not only external but also internal trade turnover. This will increase the adequacy of this mathematical model. To characterize the efficiency of the proposed algorithm, it is necessary to study the conditionality and productivity of the obtained models in two cases: using the existing (first case) and author's methods (second case) at the formation of the final consumption vector. The study showed that the author's method, wn a number of cases, allows to obtain well conditioned and productive model. Qualitative assessment of this statement is confirmed by the examples shown. The article also suggests an algorithm for final consumption vector-function finding in the model for the reporting year. An indicator of the adequacy of such a function has also been determined.

Keywords: final consumption, degenerate dynamic input-output model, condition number, productivity level of the enterprise input-output model.

\section{Introduction}

Currently, Degenerate Dynamic Input-Output Model (DDIOM) of enterprise are being actively studied. The reason for this was: firstly, accumulation of theoretical and practical economic and mathematical basis for the study of Input-Output models at different levels $[1,2,3]$, secondly, the development of mathematical methods in Russian scientific schools that allow solving degenerate systems of ordinary differential equations (Irkutsk school [4], Chelyabinsk school [5]).

Dynamic Input-Output Model has the form:

$$
x(t)=A x(t)+B \dot{x}(t)+f(t),
$$

where: $A$ is a matrix of size $n \times n$ and describes the unit direct cost; $B$ is a matrix of size $n \times n$ describes the unit capital cost; $x(t)$ is a vector of gross output; $f(t)$ is a vector of products final consumption [6].

At the enterprise level, the model considered above will always be degenerate. This was claimed by V.V. Leontieff himself the founder of the Cross-sectoral balance sheet method [6]. The degeneracy of the model is due to the presence of zero rows in the capital cost matrix. For example, such a structural element as «households» is unable to generate fixed assets, so $\operatorname{det} B=0$.

Note that in formula $(1), f(t)$ is product final consumption vector-function on the planning period. To find $f(t)$ use the following data: for each structural element for the base year, the total volume of demand for the enterprise's (column-vector $\widetilde{F}$ ); forecasted values of the growth rate of demand for the enterprise's products in the planning period. 
The existing methods (work D.V. Ruzakov and P.T. Voronkov [7], M.I. Letavin and A.A. Banin $[8,9]$ et al.) of building enterprise Input-Output models are quite similar. They include in the structure of the model only production units of the enterprise. They distinguish only production divisions of the enterprise in composition of structural elements of such model. One side, the use of such approach makes it possible to avoid the problem of degeneracy. But on the other side, it has a number of significant limitations, for example: a) the scope of application of the model is narrowed by the industry specificity of the enterprise; b) such models have a low level of adequacy, which reduces the accuracy of mathematical calculations.

In work A.V. Keller [10] proposes the idea of including three types of structural elements as branches of the model: production (business units of the main activities: production department); service (business units of the auxiliary activities: accounting department, warehouse, human resources department etc.); external (households and corporate customers). Also, considered an example of constructing the DDIOM. Then, in work A.V. Keller and T.A. Vinogradova [11, 12] developed the methodology and algorithm for constructing the DDIOM for the enterprise. At that, the author of this article for the purposes of universalization of the model shows the need to introduce an additional fourth structural element - equity movement. It reflects operations on the movement of the company's own capital and distribution of net profit. Thus, it is proposed to include four groups of structural elements in the model. This allows to analyze the economic interrelations in the model on the principle of accounting for exports and imports (used in the input-output models of the country and the region).

When analyzing the properties of the constructed models, the author found that the level of conditionality is one of the important parameters for assessing their adequacy [13]. Note that the Turing number $[14,15]$ was used to determine the level of conditionality of the DDIOM:

$$
\mathcal{N}=n^{-1} \mathcal{M}(E-A) \mathcal{M}\left((E-A)^{-1}\right)
$$

where: $\mathcal{N}$ is a condition number; $n$ is a matrix order; $\mathcal{M}(E-A)$ and $\mathcal{M}\left((E-A)^{-1}\right)$ are maximums element of the corresponding matrix, multiplied by the quantity $n$, so $\mathcal{M}(E-A)=n \cdot \max _{1 \leq j \leq n} \max _{1 \leq i \leq n}(E-A)[14,15]$.

The obtained value of $\mathcal{N}$ is characterized as a quantitative measure of conditionality. So if $\mathcal{N} \geq 10^{3}$, then the matrix $A$ is poorly conditioned, if $1 \leq \mathcal{N} \leq 100$, then it is considered that the matrix is well-conditioned [14, 15].

Another one of important parameter for assessing the adequacy of the DDIOM is the level of productivity of the matrix $A$. It is necessary explaining that further productivity analysis will be carried out on the basis of sufficient condition evaluation [16].

During the analysis of the DDIOM (constructed by the A.V. Keller's methods [10]), a low level of their productivity and conditionality was noted. Analysis of the reasons for this showed that another approach to determine the final consumption structure is needed. Thus, the presentation of the author's approach to the formation of the vector-column and the determination of the vector-function of the final consumption in the DDIOM is the goal of this article. For this did: modern methods of forming a vector-column of final consumption of enterprise products are analyzed; developed the structure of $\widetilde{F}$ for DDIOM of enterprise; developed the algorithm of formation of $\widetilde{F}$; developed the algorithm of formation of function $f(t)$. Also, the article shows that the author's algorithm will 
allow to form such $\widetilde{F}$, which, in a number of cases, will make it possible to obtain a well-conditioned and productive model.

\section{Existing Methods of Forming a Vector Column $\widetilde{F}$ in the Enterprise Input-Output Model}

At present, the column-vector $\widetilde{F}$ is understood as ksupply of products under demandњ $[8,9]$, when building enterprise input-output model. In monetary units of measurement, this is equivalent to the enterprise revenue. Figure 1 shows the formation algorithm of $\widetilde{F}$ based on existing techniques.
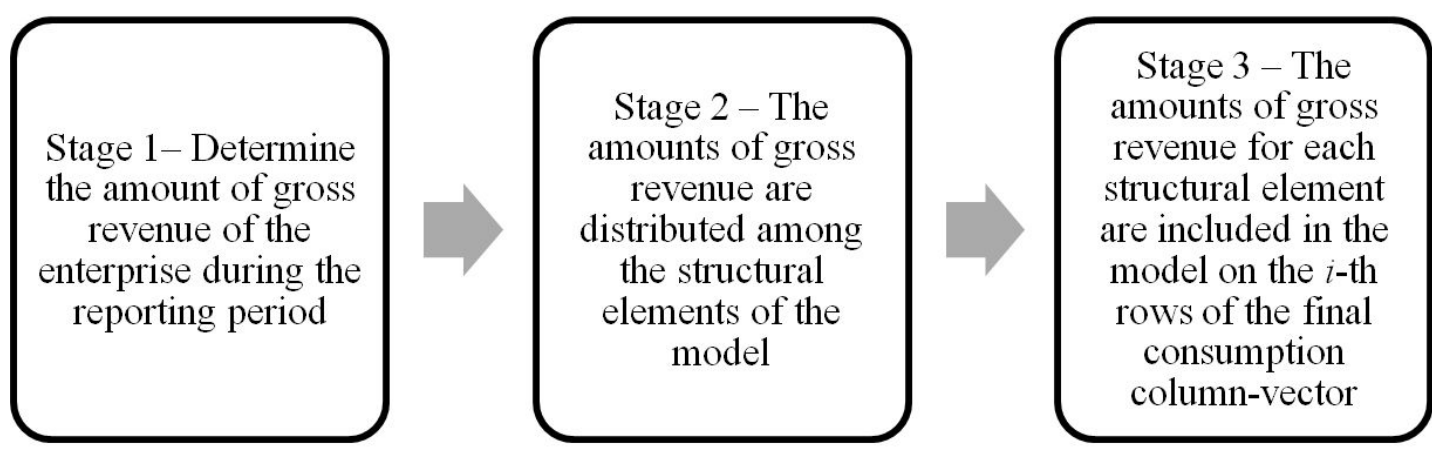

Fig. 1. Formation algorithm of $\widetilde{F}$ based on existing techniques

Next, in Table 1 we give an example of the DDIOM for one enterprise with six structural elements (1,2-production; 3, 4- serving; 5 - households and 6 - corporate consumers), in which $\widetilde{F}$ is determined by the algorithm presented above. Denote it as first variant.

Table 1

Matrices $A$ and $B$ for the DDIOM of enterprise (first variant)

\begin{tabular}{|l|l|l|l|l|l|l|l|l|l|l|l|l|l|l|}
\hline & \multicolumn{4}{|l|}{ Matrix $A, i, j=\overline{1, n}$} & Matrix $B, i, j=\overline{1, n}$ \\
\hline $\begin{array}{l}j \\
i\end{array}$ & 1 & 2 & 3 & 4 & 5 & 6 & 1 & 2 & 3 & 4 & 5 & 6 \\
\hline 1 & 0,00011 & 0,01598 & 0,00000 & 0,00000 & 0 & 0 & 0,00024 & 0,00000 & 0,00000 & 0,00000 & 0 & 0 \\
\hline 2 & 0,00862 & 0,00046 & 0,00000 & 0,00000 & 0 & 0 & 0,00000 & 0,00076 & 0,00000 & 0,00000 & 0 & 0 \\
\hline 3 & 0,01563 & 0,03244 & 0,00135 & 0,00000 & 0 & 0 & 0,00000 & 0,00000 & 0,00027 & 0,00000 & 0 & 0 \\
\hline 4 & 0,01000 & 0,03650 & 0,00000 & 0,00102 & 0 & 0 & 0,00000 & 0,00000 & 0,00000 & 0,00034 & 0 & 0 \\
\hline 5 & 0,08378 & 0,33810 & 0,99294 & 0,90719 & 0 & 0 & 0,00000 & 0,00000 & 0,00000 & 0,00000 & 0 & 0 \\
\hline 6 & 0,78986 & 0,53497 & 0,22517 & 0,06505 & 0 & 0 & 0,00000 & 0,00000 & 0,00000 & 0,00000 & 0 & 0 \\
\hline
\end{tabular}

Table 2 shows the obtained column-vectors $\widetilde{F}$ and $X$.

For this variant, the value $\mathcal{N}=6,01$. The calculated Turing number is in the range from 1 to 100. This suggests that the model is well-conditioned. But the productivity analysis of matrix $A$ showed that a sufficient condition for the productivity of the InputOutput model is not satisfied, because $\sum_{i=1}^{n} a_{i j}>1$ for $j=3\left(\sum_{i=1}^{n} a_{i 3}=1,21945\right)$. Thus, the model presented above cannot be considered productive. Next, present the author's 
Table 2

Vectors $\widetilde{F}$ and $X$ for the DDIOM of enterprise

(first variant)

\begin{tabular}{|l|l|l|}
\hline$n$ & $\begin{array}{l}\text { Final } \\
\text { consumption }\end{array}$ & Gross output \\
\hline & $\widetilde{F}$ & $X$ \\
\hline 1 & 15928,58 & 15993,38 \\
\hline 2 & 3556,50 & 3698,91 \\
\hline 3 & 0,00 & 370,60 \\
\hline 4 & 0,00 & 295,40 \\
\hline 5 & 0,00 & 3226,46 \\
\hline 6 & 0,00 & 14714,05 \\
\hline
\end{tabular}

technique for the formation of a column-vector $\widetilde{F}$ and give an example of the DDIOM for the same enterprise.

\section{Products Final Consumption Structure Analysis in the DDIOM}

When constructing the DDIOM, the final consumption will include three components. The first component is the consumption of the enterprise's products by external consumers (external demand). This is the output of the company's production divisions sold in the external environment in monetary terms, which is measured in sales revenue. Such values are calculated only by production units. An exception may be the service unit's activities, also bringing revenue to the company (they can provide outsourcing services to other enterprises).

The second component of final consumption is the consumption of products of nonproduction units within the enterprise (Intrafactory turnover). At the enterprise level, the products of non-production units will be their activities necessary to ensure the smooth operation of the enterprise in all its areas (logistics, economics, accounting, security, personnel management, etc.). In its economic nature, this part of the final consumption will be equivalent to the company's expenses for carrying out the activities of such units.

Although non-production units do not create finished products, but the costs of their activities are included in the total cost price of production units. In this connection, from an economic point of view, it will be incorrect to take into account in the final consumption only the produced and sold products of production units. And at the same time, consider such values as non-productive structural elements to be zero. It is necessary to allocate that part of production, which is created in non-productive sphere (in the form of a costs part of such activities from the final cost price) and to consider these values in a column of final consumption in corresponding lines.

The third component of the final consumption of the DDIOM contains unfinished production $(U)$ and inventories of products $(I)$ in the warehouse. These values should be reflected in the model for the systematic and complete presentation of economic information about the enterprise activities. Thus, for the enterprise's DDIOM, the final consumption vector for each $i$-th structural element will be understood as the sum of 
the demand for the products of this unit consumed both in the external and internal environment, taking into account the values of unfinished production and inventories of products for the compilation period of the model:

$$
\widetilde{F}_{i}=\widetilde{F}_{i}^{\text {out }}+\widetilde{F}_{i}^{i n}, \quad i=\overline{1, n},
$$

where: $\widetilde{F}_{i}^{\text {out }}$ is a consumption of the enterprise's products in the external environment; $\widetilde{F}_{i}^{i n}$ is a internal consumption of the enterprise's products; $n$ is a number of structural elements in the model.

The values of final consumption, with considering external demand, will be equivalent to the amounts of sold products to counterparties in monetary terms (sales proceeds).

The internal consumption of the enterprise's products is calculated by the following formula:

$$
\widetilde{F}_{i}^{i n}=\widetilde{F}_{i}^{i n V}+\widetilde{F}_{i}^{i n I}-\bar{F}_{i}^{i n I}+\widetilde{F}_{i}^{i n U}-\bar{F}_{i}^{i n U}, \quad i=\overline{1, n},
$$

where: $\widetilde{F}_{i}^{i n V}$ is a adjustment of final consumption with considering the value of intrafactory turnover; $\widetilde{F}_{i}^{i n I}$ is a inventories of products in the enterprise's warehouse at the end of the base period; $\bar{F}_{i}^{i n I}$ is a inventories of finished products in the enterprise's warehouse at the end of the period preceding the basic; $\widetilde{F}_{i}^{i n U}$ is a unfinished production at the end of the base period; $\bar{F}_{i}^{i n U}$ is a unfinished production at the end of the period preceding the basic.

Will explain that the column-vector $\widetilde{F}$ is found using formulas (3) and (4). Further, this column-vector is used to further define the unit cost matrixes of the DDIOM for the base period. For this purpose, based on the absolute values obtained (matrices of direct and capital costs, column-vectors $\widetilde{F}$ and $X$ ), the calculation of the unit cost matrixes $A$ and $B$. The structure and volume of the vector $\widetilde{F}$ influence the vector $X$, which in turn affects the values obtained $A$ and $B$. Thus, the vector $\widetilde{F}$ affects the qualitative characteristics of unit cost matrixes: their productivity and conditionality.

When constructing the model for a planning period, it is necessary to determine a vector-function $f$, depending on the time $t$. The vector-function $f(t)$ is determined analytically based on: values $\widetilde{F}$ for each month of the period, available resources, goals and objectives of the company for the planning period, etc. In the next section of the article, present the developed algorithms for vector-column $\widetilde{F}$ forming and vector-function $f(t)$ finding.

\section{Algorithms for Vector-Column $\widetilde{F}$ Forming and Vector-Function $f(t)$ Finding in the DDIOM}

Algorithm for vector-column $\widetilde{F}$ forming consist of four stages (Fig. 2).

Stage 1 - Calculation of the external demand value (gross revenue for each structural element of the model) $\left(\widetilde{F}_{i}^{\text {out }}\right)$.

The size of the external consumption of the enterprise's products is initially determined. This will be the intermediate final consumption or final external demand in the form of the received sales revenue for each structural element of the model. For all structural elements, except for production elements, the values of $\widetilde{F}_{i}^{\text {out }}$ will be zero. The exception may be when the servicing units bring the company additional revenue by providing services or performing work for counterparties. 


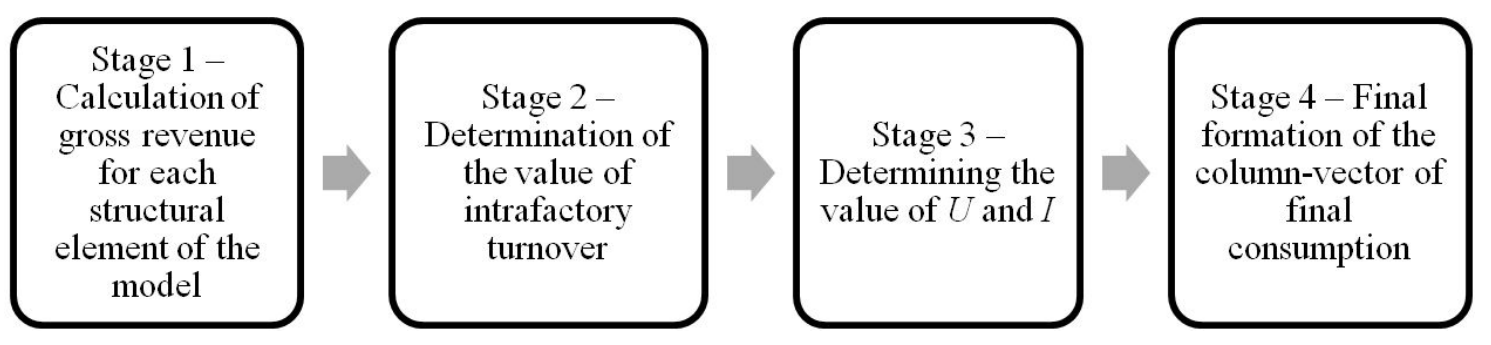

Fig. 2. Vector-column $\widetilde{F}$ forming by the author's technique

Stage 2-Determination of the value of domestic consumption of products (intrafactory turnover) $\left(\widetilde{F}_{i}^{i n V}\right)$.

In order to subsequently adjust final consumption by the value of production of nonproduction units (intrafactory turnover), the amount of expenses for performing activities of non-productive structural elements is determined. These values will correspond to the total cost in the direct cost matrix by the columns of each non-productive structural element. After that, these amounts will be allocated from the value of the external demand of production structural elements.

Such an adjustment of the final consumption, taking into account the intrafactory turnover, is possible only for production and service units. Thus, the model will reflect the mechanism of redistribution of the revenue received by production structural elements to ensure the maintenance of the functioning of the service. Such adjustment for households and corporate consumers is not necessary, since in the model in relation to the enterprise these structural elements are external.

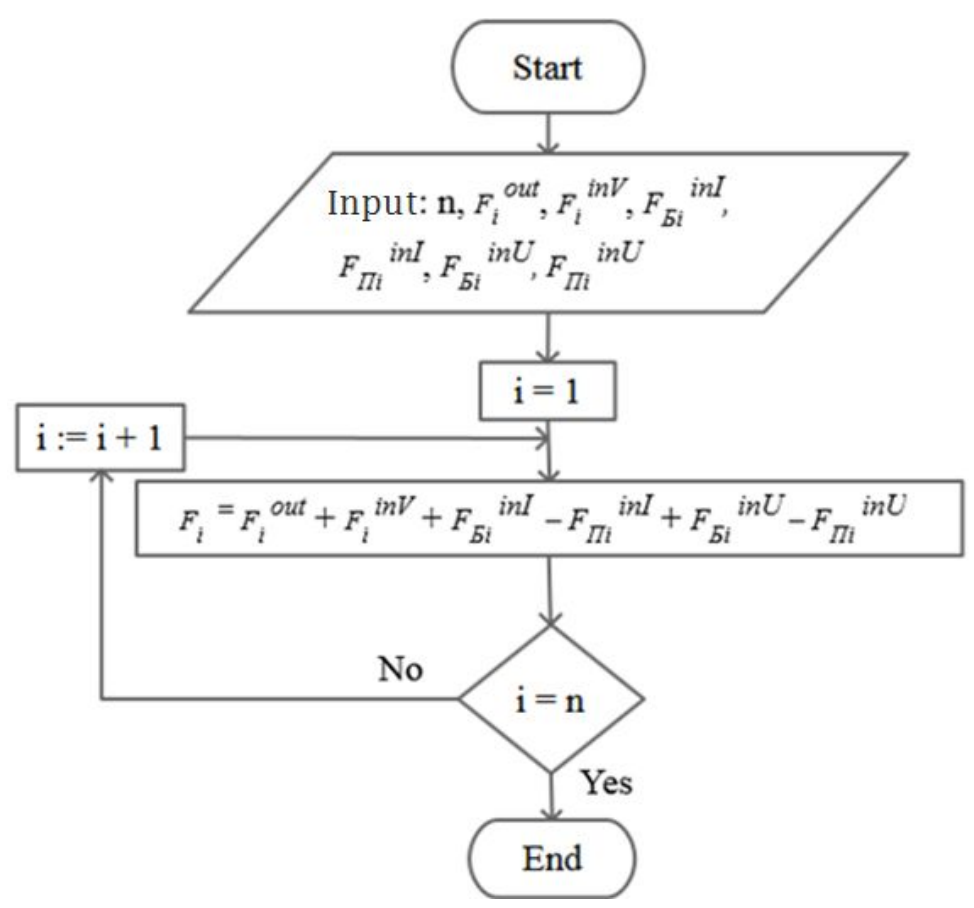

Fig. 3. Flowchart of $\widetilde{F}$ vector-column formation

Stage 3 - Determination of the value of unfinished production $(U)$ and inventories of products in the enterprise's warehouse $(I)$. 
The following values are defined for the base and preceding period: unfinished production $\left(\widetilde{F}_{i}^{i n I}, \widetilde{F}_{i}^{i n U}\right)$ and inventories of products in the enterprise's warehouse $\left(\bar{F}_{i}^{i n I}\right.$, $\left.\bar{F}_{i}^{i n U}\right)$. In this case, the corresponding values for the base period are subtracted from the values of the $U$ and the $I$ for the previous period. This adjustment of final consumption is carried out only by the structural elements of the model, which directly carry out the production of finished products.

Stage 4-Final formation of the column-vector of final consumption.

After the third stage is completed, an array of data for the final formation of the column-vector $\widetilde{F}$ will be generated, using formulas (2)-(3). For the calculation process of $\widetilde{F}$, a block diagram has been developed for each structural element (Fig. 3). After that, the final values of $\widetilde{F}$ are entered in the corresponding rows of the column-vector in the DDIOM.

In Tables 3 and 4 , give an example of the construction of an DDIOM for the same enterprise as in Section 1 of this work. Here, note that the $\widetilde{F}$ will be found by the author's method. Denote it as second variant.

\section{Table 3}

Matrices $A$ and $B$ for the DDIOM of enterprise (second variant)

\begin{tabular}{|l|l|l|l|l|l|l|l|l|l|l|l|l|l|}
\hline & \multicolumn{4}{|l|}{ Matrix $A, i, j=\overline{1, n}$} & Matrix $B, i, j=\overline{1, n}$ \\
\hline $\begin{array}{l}j \\
i\end{array}$ & 1 & 2 & 3 & 4 & 5 & 6 & 1 & 2 & 3 & 4 & 5 & 6 \\
\hline 1 & 0,00012 & 0,01655 & 0,00000 & 0,00000 & 0 & 0 & 0,00025 & 0,00000 & 0,00000 & 0,00000 & 0 & 0 \\
\hline 2 & 0,00891 & 0,00048 & 0,00000 & 0,00000 & 0 & 0 & 0,00000 & 0,00079 & 0,00000 & 0,00000 & 0 & 0 \\
\hline 3 & 0,01615 & 0,03360 & 0,00061 & 0,00000 & 0 & 0 & 0,00000 & 0,00000 & 0,00012 & 0,00000 & 0 & 0 \\
\hline 4 & 0,01033 & 0,03780 & 0,00000 & 0,00051 & 0 & 0 & 0,00000 & 0,00000 & 0,00000 & 0,00017 & 0 & 0 \\
\hline 5 & 0,08655 & 0,35020 & 0,44738 & 0,45974 & 0 & 0 & 0,00000 & 0,00000 & 0,00000 & 0,00000 & 0 & 0 \\
\hline 6 & 0,81596 & 0,55412 & 0,10145 & 0,03297 & 0 & 0 & 0,00000 & 0,00000 & 0,00000 & 0,00000 & 0 & 0 \\
\hline
\end{tabular}

Table 4 shows the obtained column-vectors $\widetilde{F}$ and $X$.

\section{Table 4}

Vectors $\widetilde{F}$ and $X$ for the DDIOM of enterprise (second variant)

\begin{tabular}{|l|l|l|}
\hline$n$ & $\begin{array}{l}\text { Final } \\
\text { consumption }\end{array}$ & Gross output \\
\hline & $\widetilde{F}$ & $X$ \\
\hline 1 & 15417,04 & 15481,84 \\
\hline 2 & 3428,61 & 3571,02 \\
\hline 3 & 451,93 & 822,53 \\
\hline 4 & 287,50 & 582,90 \\
\hline 5 & 0,00 & 3226,46 \\
\hline 6 & 0,00 & 14714,05 \\
\hline
\end{tabular}


When comparing the obtained DDIOM of enterprise in two cases it is clear that, depending on the methodology used for the formation of $\widetilde{F}$, the values of the unit costs and vectors of the models will be different. Next, we present the developed algorithm for finding the vector-function $f(t)$ for the reporting period (Fig. 4).

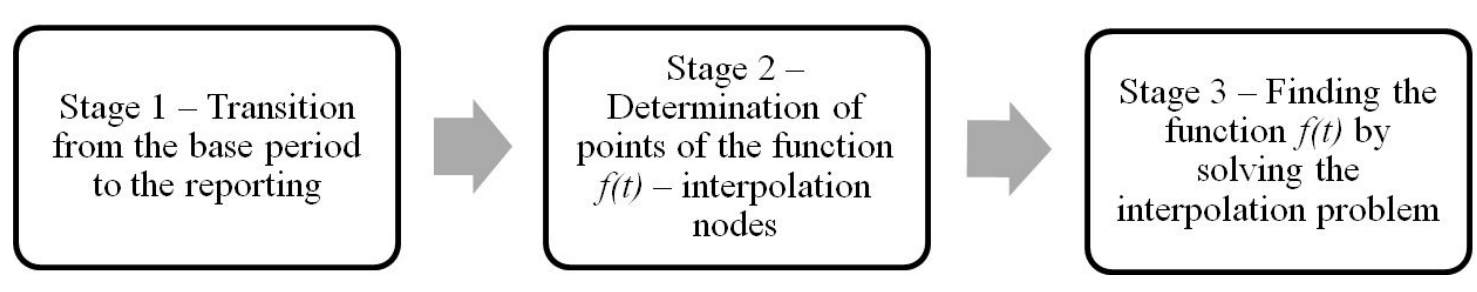

Fig. 4. Formation of the vector-function $f(t)$ by the author's method

Stage 1 - Transition from the base period to the reporting.

In the process of building the model for the planning period, it is necessary to make a transition from the base period to the reporting.

Step 1: The planned trends and the dynamics of the change in $\mathrm{F}$ for each structural element of the model are determined depending on $\widetilde{F}$. Will explain that $\widetilde{F}$ is considered a column-vector of the final consumption of enterprise products in the base period, and $F$ in the reporting period. Also, the factors of the external and internal environment of the enterprise are established, which can affect the change in the value of $F$. For example, it is established that in the planning period, in comparison with the base year, Expected total increase in final consumption of products by $5 \%$. This relationship between $\widetilde{F}$ and $F$ can be represented as $F=1,05 \widetilde{F}$.

Stage 2 - Determination of points of the function $f(t)$ is a interpolation nodes.

In order to construct the function $f(t)$, it is necessary to initially define a set of points for its subsequent interpolation. This stage includes the following steps:

Step 1: The intermediate points on the time axis $t$ are determined, where $t=\overline{0, T}$. Usually this is the first day of the month of the reporting period: January 1, February 1, etc. and then $t=\overline{0,12}$. Moreover, the interval on the $t$-axis, for example, from 0 to 1 , will correspond to the dynamics of final consumption for January.

Step 2: The reporting values $F_{i}^{r}$ (where the $r$ is a number of months in the reporting period, $r=\overline{1,12}$ ) and $F_{i}$ are determined.

Step 3: The first point of the future function $f(t)$ is determined, for $t=0\left(t_{0} ; y_{0}\right)$. This point can be determined in different ways: expert method or by finding average values for the same month in the base period.

Step 4: The point $\left(t_{1} ; y_{1}\right)$ is determined (Fig. 5) through the area of the trapezoid:

$$
S=\frac{a+b}{2} \cdot h
$$

where: $S$ is a trapezium area; $a$ and $b$ are bases of the trapezium; $h$ is a trapezium height.

For our example in January, the area of the trapezoid is the value $F_{i}^{r}$, where $r=1$. The quantity $a$ is known. The height of the trapezoid $h$ depends on the frequency of the separations of the reporting period for intermediate time intervals. For our example, when the reporting period is divided by months, the value $h=\frac{1}{12}$ Thus, only the height $b$ remains unknown. After finding this, we find the point $\left(t_{1} ; y_{1}\right)$.

Step 5: All other points of the function $f(t)$ are defined. Similar to step 4 (Fig. 6). 


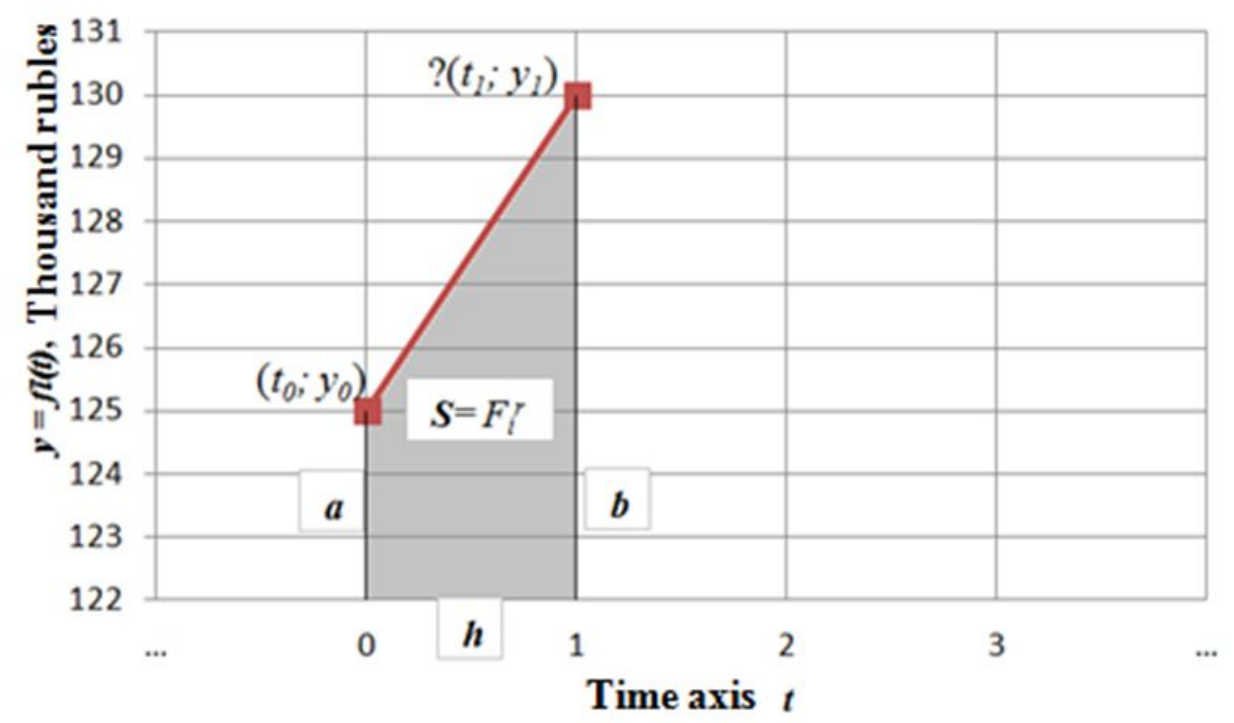

Fig. 5. The definition of the point $\left(t_{1} ; y_{1}\right)$

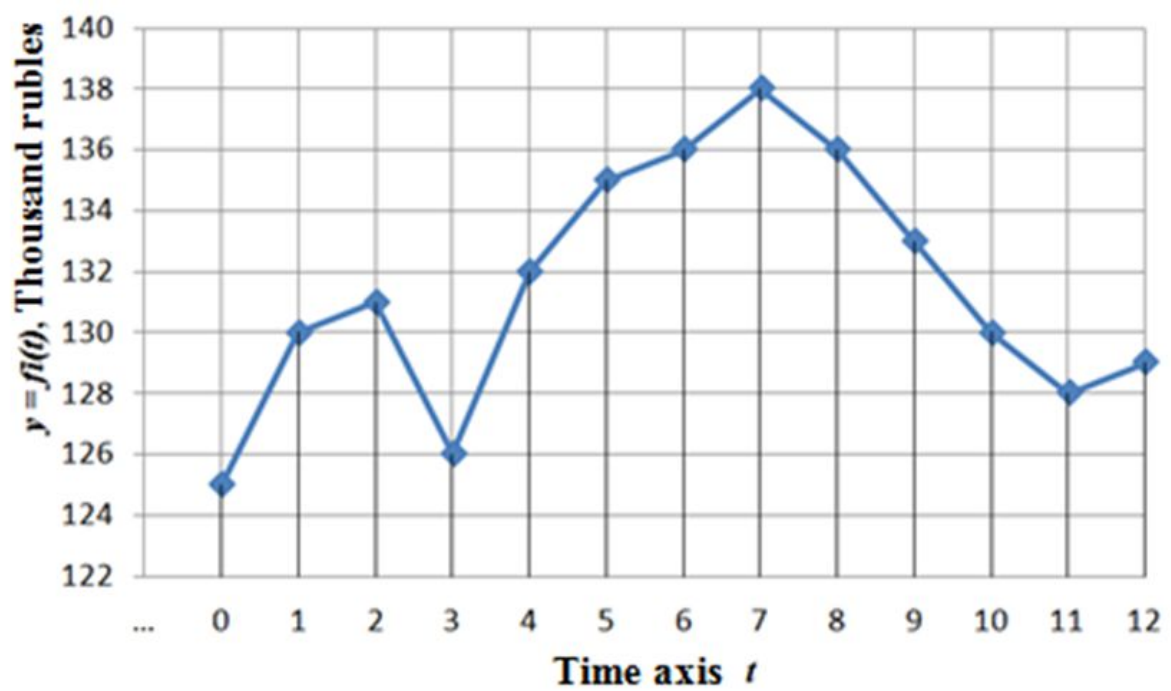

Fig. 6. The found points of the function $f(t)$

At the function is interpolated, the points found will correspond to the interpolation nodes. At the same time, the following condition must be satisfied: $F_{i}=\sum_{k=1}^{12} F_{i}^{r}$.

Stage 3 - Finding the function $f(t)$ by solving the interpolation problem. The stage contains such steps as:

Step 1: The required function $f(t)$ is found by solving the interpolation problem on the basis of the found points on the time interval $t=\overline{0, T}$. It is possible to interpolate the function in several ways, for example, using the Lagrange method.

Step 2: Checking the adequacy of the function found.

At this step, the relationship between $F$ and $f(t)$ should be explained: 


$$
F_{i}=\int f_{i}(t) \cdot d t
$$

$F$ is an indicator of the adequacy of the interpolated function $f(t)$. So, if

$$
\left(F_{i}-\int f_{i}(t) \cdot d t\right) \rightarrow \min
$$

that this indicates a high level of adequacy of the function $f(t)$ found.

In conclusion of this section, will analyze the level of productivity and conditionality of the received DDIOM (second variant) using the author's methodology of forming $\widetilde{F}$. The number of conditionality in this case $\mathcal{N}=6,12$, which also indicates a good level of conditionality of the model obtained. It is also established that the unit direct cost matrix is productive and the inequality $\sum_{i=1}^{n} a_{i j}<1, j=\overline{1, n}$ for all structural elements is satisfied.

\section{Conclusion}

The paper presents algorithms for the formation of the vector-column and vectorfunctions for the products final consumption in the DDIOM, developed by the author. Briefly list the findings:

- the structure of the column-vector of final consumption is analyzed and the technique of formation of $\widetilde{F}$ is presented. If before, the products final consumption was understood only the value of gross revenue, then now the author in the final consumption in the DDIOM proposes to include two components: external and internal consumption of the enterprise's products. For each component, a detailed description and formulas for their calculation are presented;

- the algorithm and the block diagram of the formation of $\widetilde{F}$ in the DDIOM of the enterprise for the base year are developed;

- in the examples it is shown how, depending on the adopted methodology for determining the structure of final consumption, the values of the matrices $A$ and $B$ in the model change;

- it is established that the use of the methodology and algorithm for the formation of final consumption of products proposed by the author makes it possible to correctly determine the column-vector $\widetilde{F} \mathrm{n}$ the DDIOM of the enterprise. Such the methodology allows in a number of cases to obtain a productive and well-conditioned model;

- the developed algorithm for finding the vector-function $f(t)$ in the reporting period is presented, the indicator of its adequacy is determined.

Summing up, we note that the inclusion of external and internal turnover of the enterprise in the final consumption structure will lead to more adequate subsequent modeling of the enterprise's activity in the planning period. Also it will allow to develop such managerial decisions that will improve efficiency of intrafirm planning of activity of the enterprise. 


\section{References}

1. Toroptsev E.L., Tatochenko T.V. [Modeling of Stability and Economic Growth in the Face of Uncertainty Parameters Interdisciplinary Models]. Sovremennaja jekonomika: problemy i reshenija - Modern economy: problems and solutions, 2013, no. 6, pp. 137-148. (in Russian)

2. Marakhovsky A.S. [Input-Output Balance Model as an Effective Instrument of Balance Growth Indicative Planning]. Vestnik Stavropol'skogo gosudarstvennogo universiteta Bulletin of Stavropol State University, 2006, no. 44, pp. 49-56. (in Russian)

3. Wiedmann T.A. Review of Recent Multi-Region Input-Output Models Used for Consumption-Based Emission and Resource Accounting. Ecological Economics, 2009, vol. 69, issue 2, pp. 211-222. doi: 10.1016/j.ecolecon.2009.08.026

4. Boyarintsev Yu.E., Chistyakov V.F. [Algebro-differencial'nye sistemy. Metody reshenija $i$ issledovanija - Algebraic-Differential Systems: Methods and Research Solutions]. Novosibirsk, Nauka, 1998. (in Russian)

5. Sviridyuk G.A., Brychev S.V. [Numerical Solution of Systems of Equations of Leontieff Type]. Izv. Vyssh. Uchebn. Zaved. Mat. - Russian Mathematics, 2003, no. 8, pp. 46-52. (in Russian)

6. Leontieff V.V. Input-Output Economics. N.-Y.; Oxford, Oxford Univesity Press, 1986.

7. Voronkov P.T., Ruzakov D.V. [Improving the Planning of the Results and Costs of Logging Production on the Basis of the Input-Output Method]. Lesnoj Vestnik Forestry Bulletin, 2001, no. 4, pp. 190-193. (in Russian)

8. Letavin M.I., Makarova S.A. [Dynamic Balancing Model of an Enterprise's Economic Activity]. Ekonomika - Economy, 2009, no. 4, pp. 46-50. (in Russian)

9. Banin A.A., Letavin M.I. [Application of the Input-Output Model in the Analysis of Enterprise Activity]. Ekonomika $i$ matematicheskie metody - Economy and mathematical methods, 2002, no. 4, pp. 67-73. (in Russian)

10. Keller A.V. [Numerical Investigation of Optimal Control Problems for Leontief-type Models]. DSc(Math) Work. Chelyabinsk, 2011. (in Russian)

11. Keller A.V., Shishkina T.A. [The Method of Constructing Dynamic and Static Balance Models at the Enterprise Level]. The Bulletin of the South Ural State University. Series: Economics and Management, 2013, vol. 7, no. 3, pp. 6-10. (in Russian)

12. Keller A.V., Shishkina T.A. [Use of Financial Statements as a Basis for Construction of Dynamic Balance Model for Companies]. Sovremennaja jekonomika: problemy $i$ reshenija - Modern economy: problems and solutions, 2014, no. 9 (59), pp. 8-19. (in Russian)

13. Keller A.V., Shishkina T.A. [The Number of Conditionality as a Necessary Condition for the Adequacy of the Dynamic Input-Output Model]. Yuzhno-Uralskaya Molodezhnaya Shkola po Matematicheskomu Modelirovaniyu - South Ural Yangman School of Mathematical Modeling, Proceedings of the All-Russian scientific-practical conference (Chelyabinsk, 29-30 May). Chelyabinsk, Publishing center of SUSU, 2014, pp. 74-79. (in Russian) 
14. Faddeev D.K., Faddeeva V.N. [Computational methods of linear algebra]. Moscow, Fizmatgiz, 1963. (in Russian)

15. Tsei R., Shumafov M.M. [The Number of Conditionality of the Matrix as an Indicator of Stability in Solving Applied Problems]. Proceedings of FORA, 2011, no. 16, pp. 61-67. (in Russian)

16. Granberg A.G. [Input-output models of the national economy]. Moscow, Economy, 1985. (in Russian)

Tatiyana A. Vinogradova, Postgraduate Student, Department of Mathematical and Computer Modeling, South Ural State University (Chelyabinsk, Russian Federation), shishkinata@susu.ru

Received June 23, 2017

УДК 519.86

DOI: $10.14529 /$ jcem 170305

\section{АЛГОРИТМ АНАЛИЗА СТРУКТУРЫ КОНЕЧНОГО ПОТРЕБЛЕНИЯ ПРОДУКЦИИ В ВЫРОЖДЕННОЙ ДИНАМИЧЕСКОЙ БАЛАНСОВОЙ МОДЕЛИ ПРЕДПРИЯТИЯ}

\section{T.А. Виноградова}

В статье представлен алгоритм анализа структуры конечного потребления, позволяющего корректно определять вектор-столбец конечного потребления продукции в вырожденной динамической балансовой модели предприятия за базовый год. Основной идеей алгоритма является рассмотрение в составе такого вектор-столбца не только внешних поставок продукции, но и внутреннего товарооборота, что позволит повысить адекватность исследуемой математической модели. Для характеристики эффективности предложенного алгоритма исследовались обусловленность и продуктивность полученных вырожденных динамических балансовых моделей предприятий в двух случаях: при использовании существующей и авторской методик формирования вектора конечного потребления. Установлено, что предложенный автором метод в ряде случаев позволит получать хорошо обусловленную и продуктивную модель. Качественная оценка данного утверждения подтверждена представленными примерами. Также в статье предложен алгоритм нахождения вектор-функции конечного потребления в модели за отчетный период. Определен индикатор адекватности такой функции.

Ключевые слова: конечное потребление, вырожденная динамическая балансовая модель, число обусловленности, уровень продуктивности балансовой модели предприятия. 


\section{Литература}

1. Торопцев, Е.Л. Моделирование устойчивости и экономического роста в условиях неопределенности параметров межотраслевых моделей / Е.Л. Торопцев, Т.В. Таточенко // Современная экономика: проблемы и решения. - 2013. - № 6. C. $137-148$.

2. Мараховский, А.С. Межотраслевая балансовая модель как эффективный инструмент индикативного планирования сбалансированного роста / А.С. Мараховский // Вестник Ставропольского государственного университета. - 2006. № 44 . - C. $49-56$.

3. Wiedmann, T. A review of recent multi-region input-output models used for consumption-based emission and resource accounting / T. Wiedmann // Ecological Economics. - 2009. - № 69. - P. 211-222.

4. Бояринцев, Ю.Е. Алгебро-дифференциальные системы. Методы решения и исследования / Ю.Е. Бояринцев, В.Ф. Чистяков. - Новосибирск: Наука, 1998. $224 \mathrm{c}$.

5. Свиридюк, Г.А. Численное решение систем уравнений леонтьевского типа Г.А. Свиридюк, С.В. Брычев // Известия высших учебных заведений. Математика. - 2003. - № 8. - С. 46-52.

6. Leontieff, V.V. Input-Output Economics / V.V. Leontieff. - New York, Oxford: Oxford Univesity Press, 1986. - 448 p.

7. Воронков, П.Т. Совершенствование планирования результатов и затрат лесозаготовительного производства на основе метода «затрат-выпуск» / П.Т. Воронков, Д.В. Рузаков // Вестник Московского государственного университета леса - Лесной вестник. - 2001. - № 4. - С. 190-193.

8. Летавин, М.И. Динамическая балансовая модель экономической деятельности предприятия / М.И. Летавин, С.А. Макарова // Экономика - 2009. - № 4. C. $46-50$.

9. Банин, А.А. Применение балансовой модели в анализе деятельности предприятия / А.А. Банин, М.И. Летавин / / Экономика и математические методы. - 2002. № 4. - C. $67-73$.

10. Келлер, А.В. Численное исследование задач оптимального управления для моделей леонтьевского типа: диссертация ... доктора физико-математических наук: 05.13.18. - Челябинск, 2011. - 249 с.

11. Келлер, А.В. Методика построения статической и динамической балансовой модели на уровне предприятия / А.В. Келлер, Т.А. Шишкина // Вестник ЮУрГУ. Серия Экономика и менеджмент. - 2013. - Т. 7, № 3. - С. 6-12.

12. Келлер, А.В. Использование бухгалтерской отчетности как основы построения динамической балансовой модели для предприятия / А.В. Келлер, Т.А. Шишкина // Современная экономика: проблемы и решения. - 2014. - № 9. - С. 8-19. 
13. Келлер, А.В. Число обусловленности как необходимое условие адекватности динамической балансовой модели / А.В. Келлер, Т.А. Шишкина // Южноуральская школа по математическому моделированию: сборник трудов всероссийской научно-практической конференции, 29-30 мая 2014 г. - Челябинск: Издательский центр ЮУрГУ, 2014. - С. 66-69.

14. Фаддеев, Д.К. Вычислительные методы линейной алгебры / Д.К. Фаддеев, В.Н. Фаддеева. - М.; Л.: Физматгиз, 1963. - 734 с.

15. Цей, Р. Число обусловленности матрицы как показатель устойчивости при решении прикладных задач / Р. Цей, М.М. Шумафов // Труды ФОРА. - Физическое Общество РА, 2011. - № 16. - С. 61-67.

16. Гранберг, А.Г. Динамические модели народного хозяйства / А.Г. Гранберг. - М.: Экономика, 1985. - 240 с.

Виноградова Татълна Александровна, аспирант, кафедра математического и компьютерного моделирования, Южно-Уральский государственный университет (2. Челябинск, Российская Федерачия), shishkinata@susu.ru

Поступила в редакиию 23 июня 2017 г. 